\title{
3 \\ Divided Education: Divergent Historiographies and Shared Discursive Practices
}

This chapter will show how the interpretations of the local past diverge between Bosniak and Croat historians. At the same time it will also reveal how historians on both sides draw on similar discursive strategies when narrating a national meta-narrative. These meta-narratives can best be described as goal-oriented, while Chaps. 4-6 will illustrate how the individual narratives can better be described as target-seeking. The national and the personal narratives can only be analytically divided. In reality they are tightly entangled. The national narratives dominant in the public discourse serve as reference points for individuals in many specific ways. They support, manoeuvre around and/or contest them. On the other hand, the dominant public discourse is carried on and enacted by the same individuals.

A dominant public discourse has been described as a political practice that 'establishes, sustains and changes power relations, and the collective entities (classes, blocs, communities, groups) between which power relations obtain' (Fairclough 1992: 67). Discourses contribute to the construction of 'social identities', of 'social relations' and of systems of knowledge and belief (see Fairclough 1992). However, a discourse can never be entirely captured, since it is always in the making. It is a simplification to

(C) The Editor(s) (if applicable) and The Author(s) 2016

M. Palmberger, How Generations Remember,

DOI 10.1057/978-1-137-45063-0_3 
speak of the Bosniak or the dominant Croat discourse as '[c]apturing a discourse in its totality is impossible, both because it is circulated in different kinds of written, oral and performed texts, and because it is continually evolving' (Purdeková 2008: 509). This point is particularly relevant in $\mathrm{BiH}$, where history is still, so to speak, in the process of being (re)written. Clearly, historiography is not static anywhere, but it is even less so after great political changes, such as those following the disintegration of Yugoslavia, where revising historiography has become a crucial way of legitimising new political elites. However, next to the dominant public discourses, voices of dissent can be heard. Even though these counter-voices are less powerful, they clearly matter, for example, within the media, academia, the arts and among different non-governmental organisations (NGOs) and less organised parts of civil society. In addition, there are dissenting or antithetical voices among the politicians themselves.

Referencing the local past is central to the dominant public discourses as it serves political goals. The past is used to legitimise certain ideological views on the present and on coexistence in Mostar. For example, the way national groups are presented as primordial entities that are crucially different from one another leaves little space for Mostarians to define themselves other than along national lines (Palmberger 2013).

Nationalist politicians and the nationalist-orientated media continue to dominate $\mathrm{BiH}$, fuelling distrust among people. But the nationalisation of history is not only promoted by the political elites and the media. What makes it so effective in $\mathrm{BiH}$ is the plurality of channels through which it is promoted (see Donia 2010; Torsti 2003). Besides the media and politicians' speeches, the nationalisation of history is also very actively supported by a considerable number of academic scholars and through public commemorations, memorial culture and the education system(s). Education has been said to be one of the main state-controlled redistributions of history (see Wertsch 2002); this is particularly obvious in a post-war context like $\mathrm{BiH}$ (see Hill 2011).

Still, we need to reflect critically on the influence education (including textbooks) has on the Post-Yugoslav generation. Even if we can clearly see how history is manipulated in the educational context, this does not mean that students fully surrender to the national discourses they are exposed to, as shown in this chapter and in Chap. 6. Vuckovic (2012) shows in the case of members of the Croat post-war generation that they 
evaluate Yugoslavia mostly in positive terms, particularly regarding social life, despite the negative presentations of Yugoslavia in Croatian textbooks. This suggests that we should not underestimate memories transmitted by older family members (Vuckovic 2012: 197), especially memories concerning social aspects of Yugoslavia that are widely omitted from textbooks.

\section{Institutionalising Mostar's Division: Divided Education}

In 2007, the University of Zenica in Mostar proposed plans to open a Department of Preschool Education within the Islamic teachers' training faculty. This triggered a discussion on whether such a move was legitimate or if such early religious education constitutes indoctrination and is just another mechanism of national segregation. The debate between proponents and opponents of religious pre-school education involved local as well as international actors, and attracted a lot of media attention. The international community, and in particular the Organization for Security and Cooperation in Europe (OSCE), ${ }^{1}$ expressed concerns over these developments. The OSCE justifies its active engagement in the education sector with its belief that the status quo has negative consequences for (re-)building a nationally diverse society, as expressed in the following statement: 'Children educated in monoethnic environments will likely be poorly prepared for life in such a country, let alone in an increasingly diverse Europe' (OSCE 2007a: 6; see also OSCE 2007e). ${ }^{2}$ The OSCE's intervention triggered strong reactions by Muslim clerics. Reisu-l-ulema Mustafa ef. Cerić accused the OSCE of interference in child education, which in his view should remain the business of the family (Oslobodjenje, 4 September 2007).

Even if the debate outlined above revolved around the subject of Islamic pre-school education, it was never much concerned with questions of

\footnotetext{
${ }^{1}$ The OSCE is the international organisation which most actively engages with the education sector in $\mathrm{BiH}$. The head office in Sarajevo and the field offices, such as the one in Mostar, all had their own education departments until they became part of a larger 'Human Dimensions' department in 2010 .

${ }^{2}$ The idea that education is an instrument and a resource for promoting respect for diversity is regarded as a 'Western' idea rooted in the enlightenment tradition (Höpken 2002: 11).
} 
faith but rather-almost exclusively — with the question of nationality. This is because the education system in Mostar, as elsewhere in the country, is divided along national rather than religious lines. Even if the two (religious and national) identities often overlap, it is the national rather than the religious motivation that makes many politicians, teachers and parents support a separate education system. In the case of Mostar, the segregation of children and youth from kindergarten to university institutionalises the city's division and raises a generation with hardly any encounters with their national counterparts (see Chap. 6).

In order to maintain national separatism, pupils in $\mathrm{BiH}$ are taught in separated classes using different curricula. More than three different curricula exist; the Federation of $\mathrm{BiH}$ already has several curricula, with one issued by the Federation Ministry of Education and others issued by the ministries of different cantons. A separate curriculum exists for the Republika Srpska and Brčko District. With the exception of Brčko District, all curricula show a particular national orientation (OSCE 2007a: 6; see also OSCE 2007d; Swimelar 2013). In Mostar, schools follow a curriculum either in the Bosniak or in the Croat language. ${ }^{3}$ Since there is no school following the curriculum in the Serb language, parents with a Serb background send their children to either a Bosniak- or Croatdominated school. The choice is usually influenced by the location of the school, and as no Serb-dominated schools are provided, the school is often chosen based on proximity. ${ }^{4}$

In principle, children, regardless of their national background, may attend any given school. As most of the schools are dominated by one nation, minority pupils are usually expected to accept a nationally biased curriculum. Provided there is a sufficient number of minority students, students are entitled to attend separate classes for the national group in subjects such as language, history, geography and religion. ${ }^{5}$ However, this

\footnotetext{
${ }^{3}$ Staff of the OSCE education department told me that the politically correct way to differentiate between the curricula is by referring to the language they are based on. This was also confirmed to me by students who used the terms Bosniak/Croat/Serb curriculum.

${ }^{4}$ Serb students are offered Orthodox religious education by a mobile teacher responsible for Serb students in the region.

5 'The Implementation Plan of the 5 March 2002 Interim Agreement on Accommodation of Specific Needs and Rights of Returnee Children stipulates that all schools shall organize classes from the national group of subjects, provided that parents and students opt to have the national
} 
separate teaching is provided only in rare cases. For this and other reasons, parents of minority status prefer their children to attend schools run by co-nationals, even if they have to accept long commutes. But there is also a small number of parents whose children attend classes with pupils of other national backgrounds. In conversations with parents, I learned that the reasons for such a decision are manifold and range from practical considerations to issues to do with the reputation of the school. In this discussion on separate education systems, it is important to remember that there are children from mixed marriages or children of parents with weak national identification, although far fewer than in pre-war Mostar (see Palmberger 2013).

Returning to international actors' engagement with questions of education in Mostar once more, it is interesting to note that the international community has not always propagated a common education system in the way it does now. In the immediate post-war years, the international community saw the provision of a separate education system as a necessary prerequisite to motivate refugees to return to their hometown. Although this was regarded as only a temporary solution, it showed how long-lasting the effects were for segregated schools but also for 'two schools under one roof'. The latter have two directors, two teacher councils, two student councils, two curricula and separate textbooks in the respective national languages (Ashton 2007: 11).

The staff of the international organisations who were involved in supporting two schools under one roof are aware of the paradoxical situation they have created. Over coffee, two local OSCE staff joked about it and one of them told me: 'Here in Mostar we do not have problems with two schools under one roof because we have two schools under two roofs.' It is true that in Mostar (unlike, for example, the nearby town of Stolac) the 'two schools under one roof' model has not been applied very much. Still, the most famous school that is structured on this model is situated in Mostar. The Old Grammar School, Stara gimnazija, was-as all schools were in pre-war $\mathrm{BiH}$ - a mixed school before the war. With great effort and the support of the international community, in particular the OSCE,

group of subjects taught according to a curriculum that is different from that already being taught' (OSCE 2007a: 5). 
attempts were made to reunite the school after the war (see Hromadžić 2015). Because the case of Stara gimnazija exemplifies the deadlocked situation so well and also because some of the Post-Yugoslavs introduced in Chap. 6 attended the school, I will briefly introduce the school here. ${ }^{6}$

Opened in 1898, Stara gimnazija has been housed continuously in a lovely Habsburg building, with an interruption during and shortly after the war. Before the war the school's excellent reputation was known in $\mathrm{BiH}$ and throughout the other republics of Yugoslavia. To this day, its pupils are proud to be a part of this school. Situated at the former frontline, Stara gimnazija was destroyed during the war. A few years after the war ended, the Croats rebuilt a few classrooms and claimed ownership of the school. The pre-war Bosniak students were taught in one of the primary schools instead, taking shifts with the primary school children (Ashton 2007: 8). Today, Stara gimnazija is administratively unified but students are still taught under two curricula. However, the school offers joint extra-curricular activities and recently the first integrated classes were launched (Ashton 2007: 4).

Hromadžić (2008) describes the school as an outcome of the Dayton Peace Agreement:

The school embodies the paradoxical spirit of the Dayton Peace Agreement, where simultaneous segregation (in the name of ethnic groups' survival) and unification (in the name of democratization, reconciliation, and the common national identity) of citizens take place. New forms of schools and youth—not fully integrated but not segregated, either-emerge from the collision. (Hromadžić 2008: 20)

Even if the Dayton Peace Agreement does not name the right to separate education, the agreement nevertheless leaves the central government in a weak position and the constitution emphasises national prerogatives rather than individual rights. Nevertheless more integration and mixing among the pupils of Stara gimnazija could be observed in the last couple of years. In an interview survey (Ashton 2007) with students from Stara

\footnotetext{
${ }^{6}$ I obtained information on recent developments of Stara gimnazija as well as on grander developments in the education sector of $\mathrm{BiH}$ in interviews with staff from the OSCE education department in Sarajevo and Mostar.
} 
gimnazija, those surveyed expressed little concern over mingling with students from the other curricula. Most students, moreover, did not perceive the prospect of united classes as a threat to their national identity. The report concludes:

The Gymnasium Mostar students interviewed had moved over three years from support of separate languages to believing that language was a 'silly' thing to be fighting over. This did not happen because they were forced to integrate language in school, but because they made contact with each other and, over time, began to accept each other's language. (Ashton 2007: 39)

The fears, the author of the report suggests, come more from the parents than from the students, so in fact joint activities among the parents would be needed to help overcome the barriers and scepticism (Ashton 2007: 32). ${ }^{7}$ These observations support the idea that encounters between Bosniaks and Croats-be they as limited as in the case of the pupils at Stara gimnazija - do make a difference. ${ }^{8}$ Conversely, the lack of possible encounters and contact is likely to foster prejudices and mistrust (see Hewstone et al. 2005; Lederach 1997) (Fig. 3.1).

Stara gimnazija is an isolated case in Mostar. The remaining schools keep to the separation promoted by the political elites, particularly by Croats. The language issue is taken as the core argument, whereby it is claimed that children can only learn proper Croatian if taught in mononational schools. In this discourse, the right to be taught in Croatian is a necessity in preventing assimilation. The OSCE counters such claims by referring to the Dayton Peace Agreement, which—although based on national rather than individual rights — does not include a right to be

\footnotetext{
${ }^{7}$ I was also able to observe how the fears and barriers rather were on the side of the parents than the teachers during my previous research in Brčko. Since the 2002 school year, in Brčko, students are together for more than $80 \%$ of the time and only national group subjects are taught separately (see OSCE 2007d: 29). After overcoming initial difficulties, Brčko's education system today has a very good reputation and even students from across the border come to Brčko for their education.

${ }^{8}$ Creating opportunities for young people to meet is a central aim of some of the youth NGOs in Mostar, such as the youth centres OKC Abrašević, Nansen Dijalog Centar (Nansen Dialogue Centre) and Mladi most (The Young Bridge) — as I learned in interviews with these youth centres' staff and from regular visitors. The events I attended at these centres proved successful, even though only a small percentage of Mostar's youth participated in their projects.
} 


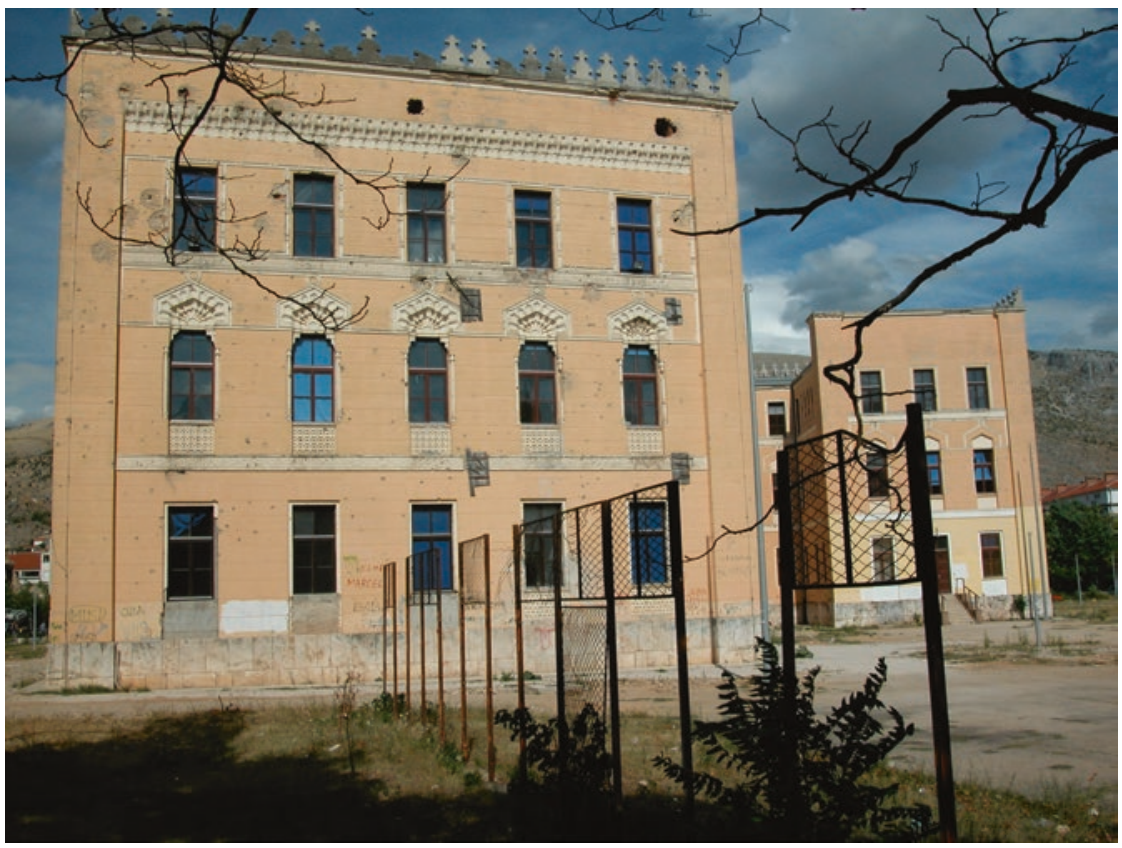

Fig. 3.1 Stara gimnazija, the Old Grammar School in 2008. Photo by the author

taught in one's language: 'While the right to learn one's own language is guaranteed, there is no guarantee in any convention or in the $\mathrm{BiH}$ and Entity constitutions that peoples have the right to be taught in a particular language' (Ashton 2007: 9). Yet we should be aware that the position of the international community towards the language issue is itself ambivalent. For example, on the one hand the OSCE does not support the idea that children should be taught in their respective languages, while on the other hand all official OSCE documents (and its website) are written in all three official languages: Bosnian, Croatian and Serbian. This OSCE practice strongly signals the need for linguistic separatism.

Aside from language, the curriculum acts as another strong boundary marker. Even if textbook commissions have 'cleansed' the textbooks of obvious offensive content towards co-nationals, it does not mean that current textbooks are not biased. In 2008, an analysis of 20th-century 
history textbooks for the final primary school grades was launched by the Georg Eckert Institute for International Textbook Research. The report of the analysis reveals that the quality of the textbooks differs greatly in respect to the Guidelines for writing and evaluation of history textbooks for primary and secondary schools in BiH adopted in 2006. One of the central principals of the Guidelines states that the region and the country of $\mathrm{BiH}$ have to be the main reference points in the textbooks (see Karge 2008: 22). The selected textbooks used for the curriculum in Croatian and Serbian ignore this guideline and instead take as their reference point Croatia or Serbia, respectively. Textbooks taking $\mathrm{BiH}$ as their reference point, however, are similarly biased by tending to focus on Bosniak history rather than presenting a balanced account of the history of all the nations in $\mathrm{BiH}$. This analysis also corresponds with my observations during history lectures at Mostar's two universities discussed later in this chapter.

At present, the war of the 1990s is not part of the curriculum in most of the cantons of the Federation of $\mathrm{BiH}$, but is part of the curriculum in the Republika Srpska (Karge 2008). Most of the cantons of the Federation of $\mathrm{BiH}$ follow a recommendation by the Parliamentary Assembly of the Council of Europe expressed in 2000 that suggests excluding the war of 1992-1995 from the schools' curriculum. This does not mean, however, that textbooks do not deal with the recent war at all, but they do so in very different ways. The space provided for such a discussion varies greatly, as does the quality of historical analysis. The fact that even the date given for the outbreak of the war in $\mathrm{BiH}$ differs says a lot. While the textbooks identifiable as Bosniak-biased and Serb-biased date the outbreak of the war to the day of the EU's recognition of $\mathrm{BiH}$, the textbook identifiable as Croat-biased gives a much earlier date, namely 5 October 1991, when an attack against the Croat-dominated village of Ravno in Eastern Herzegovina was launched by JNA forces (see Karge 2008).

Even if the war in the 1990s is not covered in the curriculum of Canton 7 (the canton to which Mostar belongs), it is likely that discussion of the war finds its way into the classroom. Regardless of the content of the textbook, its use is up to the teacher. We can assume that in both directions - towards a balanced understanding or towards separatismteachers find a great spectrum of possibilities in what and what not to 
teach their students. ${ }^{9}$ As I observed in Mostar, teachers would often bring a whole school class to attend a commemoration ceremony, most of which were in remembrance of the 1992-1995 war. This was, for example, the case in Mostar on 14 June 2006 when an exceptional history lesson took place under the Old Bridge. In order to illustrate the way in which history is taught to students at commemorations and how memories are transferred from the older generations to the younger, let us take a closer look at this particular commemoration ceremony.

My notes from my Mostar field diary on 14 June 2006 state:

An exceptional history lesson is taking place under the Stari most today. What makes it exceptional is not only the location but the choice of 'history teacher'. The event is being organised by the Army of Bosnia and Herzegovina $(\mathrm{ABiH})$ and the 'history teacher' is one of the former soldiers who fought for the $\mathrm{ABiH}$ during the war between 1992 and 1995. The event is one of a series of events to celebrate the liberation from SerbianMontenegrin aggression and is announced as a 'history lesson'.

It is a bright, sunny day and I arrive a bit early at the Šehitluci (martyrs' cemetery, Fig. 3.3) waiting for the pupils and teachers to arrive. All the children who arrive have a red carnation in their hands. Soon the crowd grows and it becomes a noisy, cheerful gathering. Kids are very excited, talking to each other, giggling and waving their flowers in the air. The excursion seems to be a welcome change; nothing yet reminds us of the serious purpose behind the event. A handful of soldiers and the imam stand out amid the cheerful youngsters. A few children have wreaths in their hands, waiting to lay them on the martyrs' graves.

The cheerful noises quieten down once the official ceremony begins and a soldier lays a wreath at the martyr's grave while the imam says a

\footnotetext{
${ }^{9}$ Although this section has concentrated on the aspects of a divided education system, it does not mean that this is the only problem students face. Students and parents have expressed to me great dissatisfaction with teaching methods as well as school facilities. One tremendous shortcoming is the lack of space, and it is not uncommon that secondary school children are taught in primary schools, especially in East Mostar (see OSCE 2007c, n.d.). Despite the defects of the education system in $\mathrm{BiH}$, there are also pupils from families in economically disadvantaged situations who are not able to attend school at all (see OSCE 2007b).
} 
short prayer. Afterwards the imam addresses the children by telling them that the soldiers of $\mathrm{ABiH}$ gave their lives for their future, for their tomorrow and their fortune. 'We will never forget them!' he announces with such pathos that it comes across rather as, 'We are never allowed to forget them!', pointing towards the graveyard where these words are inscribed on a plaque. 'You have to listen carefully to what you hear in school and you should never forget!', he tells the young audience. 'It does not matter if it is written down in books or not, Tuđman was our enemy!', he concludes and invites the pupils to join him in the history lesson under the Stari most.

The crowd moves from the cemetery through Stari grad (Old Town) to Stari most. The long caravan of children wave their red carnations in excitement. Arriving on top of the bridge, they let the carnations sail down into the Neretva River, which soon turns into a sea of red flowers.

After crossing the bridge, the pupils pass the stone-carved sign, 'DON'T FORGET '93' (written in English, Fig. 3.2). The memorial

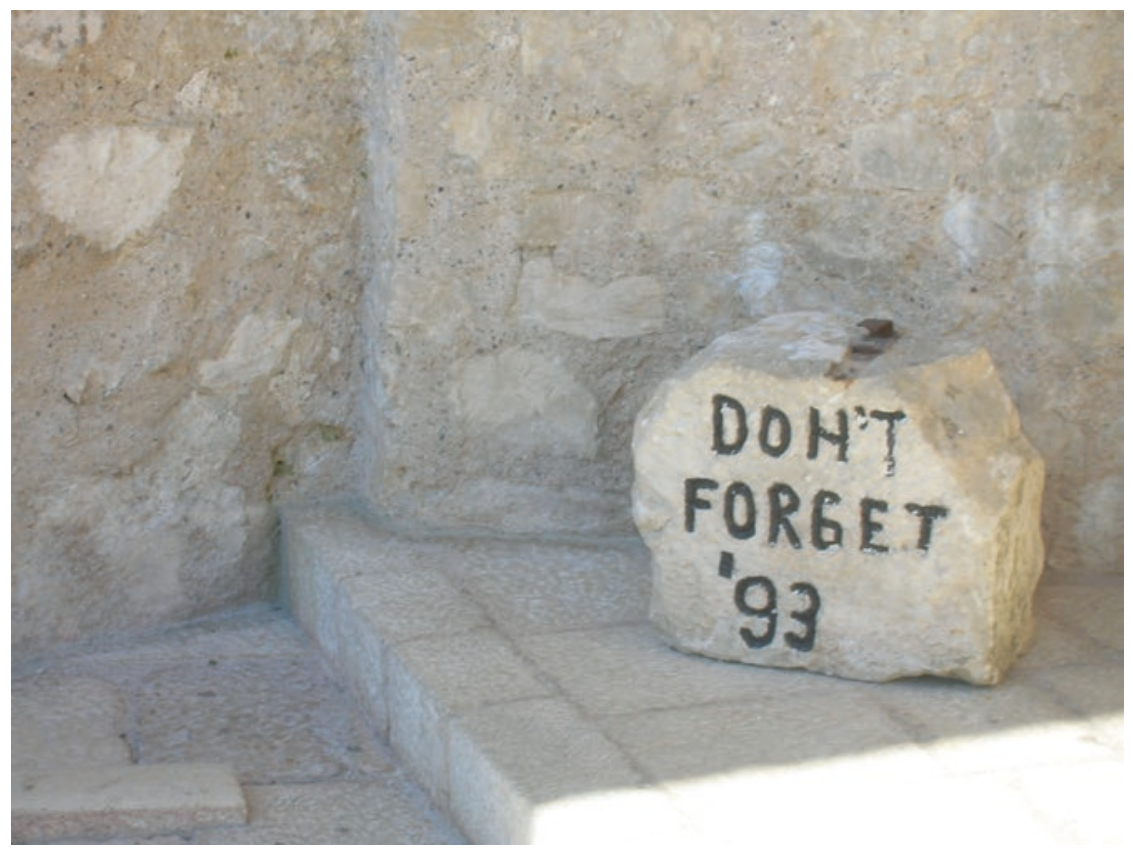

Fig. 3.2 A memorial stone at the Old Bridge. Photo by the author 


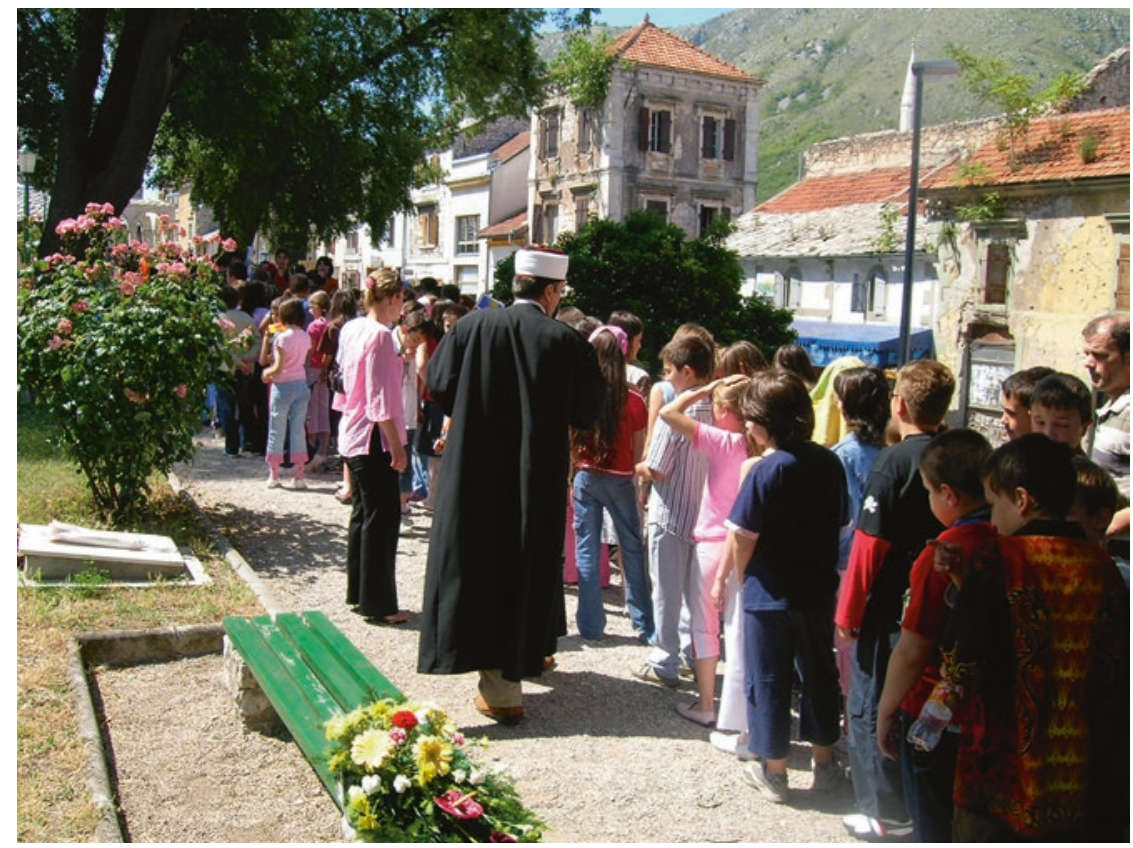

Fig. 3.3 The imam with pupils at Šehitluci (martyrs' cemetery), 2006. Photo by the author

stone reinforces what the imam has just told them. Not all pupils seem to notice it, but some do and point in the direction of the stone with their carnations. The caravan moves down to the riverbed to a stage from which loudspeakers burst out popular folk music. The children's excitement increases from being so close to the water. Some of them have little $\mathrm{BiH}$ flags in their hands. Listening to the music being played, I notice that it is a song about Tuđman, accursed enemy of beautiful BiH. After two men dive from the bridge into the river (an old tradition associated first and foremost with Mostar's pre-war identity and which today is almost exclusively practised by Bosniaks), the ceremony reaches its peak, the announced history lesson. A man in his early 50s takes the stage and address the audience:

I wish to tell you a story ( $p$ riča) today. A true story with a beginning and an end. So far you have heard different kinds of stories. Stories that began 
with 'once upon a time, behind seven mountains and seven seas'. This kind of story you will not hear from us today. Our story has a real beginning, has a date, a day and time: 14 June 1992, one of the most important days in the history of Bosnia and Herzegovina, in the entire thousand-year old history of Bosnia and Herzegovina.

The soldier continues by introducing himself as one out of many $\mathrm{ABiH}$ soldiers. By claiming that he is only one of many, he suggests that soldiers were not fighting as individuals but as a collective; from this point his story is the story of the $\mathrm{ABiH}$ or of 'the' brave soldier. From the beginning, the speaker makes clear that he is not only a teacher of history but, more importantly, a participant (učesnik) of history. This gives him the legitimacy to speak about the past. Moreover, his words seem to suggest that he, as a frontline soldier, really saw what happened, in contrast to those civilians who stayed at home. He embeds the day, 14 June 1992, within a question about the wider history of $\mathrm{BiH}$. The day of the liberation from Serbian-Montenegrin forces occupying Mostar is described as one of the most meaningful days in the long struggle for independence of $\mathrm{BiH}$ and the freedom of the Bosniak nation. But before finally achieving independence, the Bosniak nation once again became a victim. The victory of the day in question against Serb forces is narrated by the speaker as the beginning of Croat aggression:

The entire left bank of our beauty [Neretva River], meaning this part which lies behind us, was occupied and all people, good people, had to leave their homes. On 13 June 1992, the first crossing of the River Neretva succeeded. When we arrived, our two blessed [here the old Turkish expression rahmetli is used] friends waved their flags with the lilies on it, flags which I see in your hands. And we thought that it was the end of aggression against our city. But as we soon learned it was the beginning, the beginning of a heroic fight $[\ldots]$.

In this part of the speech, it becomes clear that the Bosniaks are portrayed as the victims but also that the soldiers fighting back against the aggressors are the new heroes. When referring to the beauty of the Neretva, the speaker anchors the nation's identity in nature. The Neretva River is the natural beauty that persists even when dark forces are trying to destroy it. It is 'our' (the Bosniaks', not the Croats') Neretva, which, together with 
the Stari most, constitutes two strong identifiers for the Bosniak nation. The flags in the children's hands serve as the symbolic link between the children and the past. Although the speaker refers to the lilies on their flags, the lilies are no longer on the official flag of $\mathrm{BiH}$, the flags the children hold in their hands. Since the fleur-de-lis is closely associated with the Muslim population it could not remain on BiH's flag, so it gave way to a nationally neutral flag that was adopted in 1998 under the authority of the High Representative.

The day in question was the beginning of a heroic fight for liberation to allow the young generation to live a free life, the soldier continues. Only owing to the heroic deeds of the battalion $\mathrm{ABiH} 401$, 41st brigade, can the pupils live in a free city. It soon becomes clear, though, that this privilege is not free of demands, but requires responsibility and gratitude from the youngest generation. The mission that the youngest generation is entrusted with is formulated by the soldier in an authoritarian tone: 'You should never allow anyone to do to you what was done to us!'suggesting that the war affected only the older generation and at the same time asking for lifelong gratitude towards the veterans and martyrs. In the speech, the speaker indicates that not only the $\mathrm{ABiH}$ but also the Islamic faith saved the Bosniak nation and therefore the youngsters are asked to pray whenever they pass martyrs' graves.

At the end of the speech, the soldier appeals to the young generation to listen to their parents and teachers (implying that they know the truth, unlike some books, as suggested earlier) and to take it into their own hands to fight against evil and dark forces (sile zla, sile mraka) so that history does not repeat itself. Although the dark forces are never named, it is clear throughout the speech where they are located, and in order to erase any remaining doubts, the song with the words 'Tudman is our enemy' in its refrain is played at full volume once more at the end of the speech.

The central message of the soldier to the pupils was simple: there are good people (we Bosniaks) and there are bad people (Serbs and Croats), and even if we have won the fight we have to remain vigilant in the future. The entire history lesson had one clear goal, namely to strengthen the sense of a Bosniak nation and to reinforce the division between Bosniaks and Croats (and Serbs). Although it was (at least in 
the announcement) intended to be a commemoration celebrating the end of Serb-Montenegrin aggression, the event was clearly used first and foremost as a reminder of the Croat aggression that was portrayed as a danger until this day.

Dubravka Ugrešić, a Croat writer who in 1993 went into exile to escape nationalist politics in her home country, refers to such commemorations as 'terror[s] of memory'. Such events are evoked in order to re-install the continuity of national identity (Ugrešić 1998: 123; see also Van der Veer 2002). The national memory is thereby narrated through the central dichotomy of a collectively threatened body (us) versus a collectively threatening body (them) (Ugrešić 1998: 117). Considering the riots that took place the night before the commemoration-when Croat hooligans, after losing against Brazil in the World Cup championship, rioted around the Bulevar and eventually picked a fight with their Bosniak counterparts - it was probably easy for the pupils to make the connection to where the 'dark forces' might be located. Although this incident was clearly related to hooliganism, the local and international media described it as renewed 'ethnic violence' in Mostar, reinforcing fear and division in the city.

In order to further analyse the national dominant discourses and the discursive strategies employed to support it, in the remainder of the chapter I mainly draw on material gathered from a range of different university lectures on the history of $\mathrm{BiH}$ (and Croatia) in the 20th century held at the Bosniak-dominated Univerzitet Džemal Bijedić Mostar and the Croat-dominated university Sveuciliste u Mostaru in 2006. My data is also based on conversations and interviews I conducted with historians and students of history. So far, research on the role education plays in propagating nationalist thinking in $\mathrm{BiH}$ has concentrated on textbooks (see, for example, Karge 2008; Torsti 2003) rather than the way in which history is taught in the classroom. While in textbooks only the historiography presented by a particular author can be analysed, in the classroom we can observe rhetorical means as well as moments of contestation. By including the interaction between lecturers and students at the two universities, we can also learn more about cross-generational dialogue. 


\section{Rewriting History and Placing the Nation}

In the foreword to his book Myths and Boundaries in South-Eastern Europe Pål Kolstø writes:

Groups that share the same history often interpret their common experiences in radically different, sometimes diametrically opposite ways. The stories they tell about themselves and others-autostereotypes and heterostereotypes - may all be based somehow on historical 'facts', but are so radically embellished that they hardly resemble each other any longer. (Kolstø 2005: vii)

This description greatly resembles my experiences when attending lectures on the history of $\mathrm{BiH}$ (and Croatia) in the 20th century at the two universities in Mostar, when I participated in commemorations, and the observations I made through reading local newspapers and watching TV reports on the local past. During my participant observation at the two universities, I sometimes had to hurry from one university to the other between lectures. On arriving at the university on the 'other side', it felt as if whole worlds lay between the historiographies I heard in the respective lecture halls.

As briefly mentioned above, two universities have existed in Mostar since the war: Univerzitet Džemal Bijedić Mostar (mainly referred to as Džemal Bijedić here) on the east side, and Sveučliste u Mostaru (mainly referred to as Sveuciliste, meaning 'university' in Croatian) on the west side. At the former, the majority of students are Bosniaks and a number of the professors are affiliated with the University of Sarajevo. At the latter, most students are Bosnian Croats, but there are also a number of students as well as professors from Croatia. From the Bulevar dividing East and West Mostar, a street lined with old trees leads to Sveuciliste. Many cafés are situated along the street and posters adorn the old trees, making students aware of upcoming student parties and pubs with special student offers. Sveućiliste is located only around 50 metres away from the Partisan memorial cemetery and some hundred metres from the football stadium, which in the eyes of the Bosniak population was unjustly taken away from Mostar's pre-war football club Velež (previously a multinational 
club and today Mostar's Bosniak football club; see Mills 2010). In the meantime it has become the home stadium for the West Mostar football club Zrinski, the arch-rival of Velež. Due to its national affiliation Zrinski had been forbidden and disbanded in socialist Yugoslavia but was re-established in 1992 with a ceremony held in Medjugorje, the Marian pilgrimage place.

So Sveučiliste is in-between two highly contested places, the Partisan memorial cemetery and the football stadium. The former is contested first and foremost by Croats because it 'worships' the socialist heroes, while the latter is contested mainly by Bosniaks who claim entitlement to the place. The third highly contested place is the building of Sveucíliste itself. Sveučiliste is based in the pre-war university building whose premises were used as a prison camp during the recent war. ${ }^{10}$ Although this part of the building's history is not visible, other signs of its past are recognisable. For example, one of the lecture halls at the time still housed a world map in Cyrillic letters, a leftover from the old university. It seemed even more out of place when considering the pictures on the wall next to it, displaying Christian themes central to Croats' self-understanding. For example, one of the pictures was titled, 'Pokrstenje Hrvata', meaning 'Baptism of Croats'.

Sveučiliste, which prides itself as being the only Croatian-language university in $\mathrm{BiH}$, sees its roots in the Franciscan Theological School, which was founded in the late 19th century and closed in 1945. This affiliation with the Franciscans is also visible in Sveučiliste's logo, which shows the building of the Franciscan Monastery in Mostar. Sveućiliste receives considerable financial support from Croatia and is therefore much better equipped than its Bosniak counterpart. This close relation with Croatia was expressed in and reinforced by the large-scale reconstruction of the university buildings - begun at the end of my fieldwork - which was extensively funded by Croatia.

It is on the premises of Sveuciliste where the pre-war university (and Mostar's only university back then) was located. When in 1993 war began between Croats and Bosniaks, the Croats took over the university building and equipment. A group of Bosniak staff and students who

\footnotetext{
${ }^{10}$ This information I received in an interview with staff at one of the Bosniak detention camp victims organisations in Mostar.
} 
were able to flee to the left bank of the Neretva meanwhile continued to work in the memorial house Džemal Bijedic ${ }^{11}$ under extremely hostile conditions (Univerzitet Mostar 2002: 18). In 1994 the University Džemal Bijedićwas relocated to the former Yugoslav Northern Camp army barracks (sjeverni logor), which had been heavily damaged during the first year of war. Thus the war was also tangible to me, not only in the presentations of the lecturer-where history was often examined from the perspective of the recent war-but also on the university's premises. The classrooms only have basic equipment and do not provide sufficient heating during wintertime. On a rainy day, looking at the ruins through the barred window of one of the lecture halls is rather depressing. But when the sun is out, the former military camp turns into a lively university campus with a café packed with students in its centre and loud local rock music bursting from the speakers.

The history department was still very new when I did my fieldwork and the first students were expected to graduate in 2006. This relatively short history of the department, as well as the university as a whole, and its difficult start, were still noticeable during the time of my fieldwork. For example, several times during my fieldwork, classes were cancelled without the students being informed in advance or indeed being informed at all. I had plenty of opportunities to interact with students outside of the classroom, joining them during coffee breaks and even making friends with students from different faculties. In these informal settings I also gained insight into the less enjoyable parts of their academic lives, which had to do with the poor university infrastructure (practical issues such as insufficient heating in classrooms, and more substantial concerns such as restricted access to literature) and the absence of some professors over long periods (as they often teach at other universities and only come to Mostar for limited periods). ${ }^{12}$

Although the two universities are divided along national lines, a group of minority students from the respective other side does exist. This 'cross-

\footnotetext{
${ }^{11}$ Džemal Bijedić was prime minister of Yugoslavia from 1971 until his death in an airplane crash in 1977. Born in Mostar, he had felt a special responsibility to put his home region back on the map. Under his influence, significant progress regarding the economy and higher education was made in Herzegovina. Due to his patronage, Mostar's university, opened in 1977, was named after him.

${ }^{12}$ For a critical assessment of the university system in $\mathrm{BiH}$, see Weber 2007.
} 
ing' is an academically strategic choice students make rather than a choice based on political considerations. For example, Sveuciliste did not offer computer sciences at first. So, the only option for students with a Croat background wanting to stay in Mostar but hoping to enrol in computer sciences was to study at Džemal Bijedić. From conversations with such students, I learned it was not always easy for them to convince their families that this was the right thing to do. Parents were afraid that they would face harassment and discrimination on the 'other side'. Another reason students gave for studying on 'the other side' was to avoid having to take a difficult entry exam. In the case of national subjects (such as Bosnian or Croatian language and history), however, the barrier seems insuperable even if it conflicts with personal interests. One young history student I met at a seminar for multi-perspective textbook writing told me he is most interested in the Ottoman period. But I was surprised to learn he was studying at Sveuciliste because I had thought that this period would be taught in more detail at Džemal Bijedić. Although the young historian confirmed my assumption, he made it very clear that he, as a Croat, would want to study history at Sveućiliste.

\section{Objectifying History}

As Borneman states, historians are granted exceptional authority in speaking of the past:

Unlike an individual, a state has, of course, no memory by which it can reconstruct anything. It cannot at any point in time tell you its history, though historiographers may take it upon themselves, often with state approval, to do so. (Borneman 1992: 42-43)

In $\mathrm{BiH}$, historians are the spokespeople not of the state, but rather of their respective nations. They are central actors in providing proof of the nation's legitimate existence. For that reason, authors critical of such historians have referred to them as 'ethno intellectuals' (see, for example, Sekulić 1999: 283) or 'national historians' (Donia 2000: 358). They are given authority to speak about/for the nation's past, and what they say possesses a strong normative value. Their authoritative power makes it easy 
for their words to be exploited for political means. Following Bourdieu (1992: 116), I suggest we speak of the symbolic efficacy of the words of those people recognised by others as individuals holding authority:

The power of words is nothing other than the delegated power of the spokesperson, and his speech-that is, the substance of his discourse and, inseparably, his way of speaking - is no more than a testimony, and one among others, of the guarantee of delegation which is vested in him. (Bourdieu 1992: 107)

This authority to speak in the name of the nation was also emphasised by lecturers I encountered at the two universities. Generally a rather positivist approach towards history was taken. The lecturer has the authority to tell the students which historical interpretation is right and which is wrong.

This became most clear when a student's view on history diverged from that of the lecturer. This was, for example, the case when a student at Sveuciliste compared the crimes committed by the NDH regime to those committed by the German Nazis. This caused the lecturer to interrupt the student by asking what literature he had actually consulted. The student mentioned that one of his references was a source from the internet and the other a book, the title of which he read to the class. Thereupon the lecturer reprimanded the student for not having been critical enough in his literature review, claiming the literature and website consulted were nothing but propaganda. Trying to persuade his students to be more critical when consulting books, the lecturer explained that a book is not authoritative per se. He then began asking students whether they thought a nation's fight for its rights was understandable. It was true that crimes were committed by the NDH, he admitted, but added that every national liberation struggle in history had been bloody: 'What do you think? What would you do if you had to defend your nation?' He then explained that the Serbs had positioned themselves against the Croats in WWII, while the Partisans had fought against the Nazis only to proclaim a communist revolution. The lecturer continued by saying that one cannot only look at what had happened but always had to ask why something had happened as well. At the very end of the lecture, he once again looked straight into his students' eyes and repeated his plea for a critical reading of historical documents. 
The lecturer made it clear to the student that his representation of history was not acceptable at all, first by criticising the choice of literature, then his uncritical reading of it, and finally the presenter's analysis itself, as the student had only looked at the events and had not asked why the $\mathrm{NDH}$ had resorted to violence. In his explanation, the lecturer partially admitted that what the student had said was correct, although his interpretation was not. In a conversation outside the classroom, the lecturer once told me that national identity becomes most important when it is threatened and that in contrast to well-established nations, such as France, nationalism in former Yugoslavia was still in its infancy. 'How can one ask a 10 year old to behave like a 20 year old?' he rhetorically asked me.

The lecturer's unequivocal reaction shows that only one interpretation of history is acceptable in the class. This interpretation of history stands in stark contrast to the one taught in socialist Yugoslavia, where the NDH regime was referred to as the enemy within who collaborated with the Nazi oppressors (see Chap. 2). Instead, the lecturer's interpretation is in line with that of the first president of Croatia (also a historian), Franjo Tuđman, who downplayed the number of victims of the NDH (see Campbell 1998). Similar to the lecturer's argument above, Tuđman had stated that when looking back in history, one could see that all national liberation movements were violent to some degree (the same argument is often made to justify or at least downplay the crimes committed by the HVO in the wars between 1991 and 1995). ${ }^{13}$ At the same time, when crimes committed by Croats are downplayed (or whenever possible, silenced) the victimisation of Croats is emphasised. For example, the dominant Croat public discourse claims that Tito discriminated against the Croat people because of the crimes committed by the NDH.

History was taught in a similar authoritarian and positivist fashion at Džemal Bijedić, even if there the opinion was upheld that history teaching in $\mathrm{BiH}$ does not need to be separated along national lines. In an interview I conducted with a lecturer of the history department at Džemal Bijedic, teaching 20th-century history, he clearly positioned himself

\footnotetext{
${ }^{13}$ With the election of Croatia's new Prime Minister, Ivo Sanader, in 2003, and the political changes that followed his assumption of office, Croatia has taken a clear position regarding Jasenovac, condemning the crimes committed by the NDH regime. In 2004 a memorial site in Jasenovac was officially opened and representatives of the church, the Jewish community, as well as the Serb minority and the highest politicians of the country, were present (Melčić 2007: 558).
} 
against nationally biased historiography without questioning the idea of 'objective history' as such. The lecturer promoted a history without (national) emotionality, based purely on facts. He indeed argued that science has to aim for objectivity and should not be misused for national chauvinistic purposes. He indicated that he had no categorical objections about the two universities in Mostar as long as they were not oriented along national lines. This lecturer's perception was crucially different from that of the Croat lecturer's discussed earlier in this chapter, who viewed the existence of a Croatian-language university as a crucial precondition for the national survival of the Croat people in $\mathrm{BiH}$. However, it soon became clear that it is the historian who has the authority to claim historic objectivity. In order to make the Bosniak lecturer's position clearer, here is an excerpt from my interview with him:

\section{Are there Croat students at your department?}

I think we have some, but only a small and insufficient percentage. Why do I think this? History is a national subject and when it comes to national subjects like language, history and culture, students mostly believe that they can only study this subject at one of the two universities. My opinion, frankly, is that students of every nation, not only Croats or Serbs but other nations too, Jews... why not? They are welcome to study at this faculty. We are gaining knowledge of the history of Bosnia and Herzegovina. We decided right from the beginning that our knowledge of history has to be based on documents, not emotions. I'm always telling my students to exclude emotions. [...] History is really sensitive in that sense and we are really trying to be careful not to include those emotions, no matter if this is a national subject; we have to analyse our history, our culture, and tradition on the basis of real facts. I don't think only of Bosniaks in $\mathrm{BiH}$, but of all nations, why not? All of that is our historical-cultural surrounding in which we have developed. We don't gain knowledge of the history of Bosniaks or of Bosnian culture, we don't have those subjects, our subject is history [...].

Do you think objective history is possible?

Yes, why? Absolutely yes, why not? History is beautiful, if it is not misused... could we have objective history? Well, if we are going to consider only science, only science and facts, if we are building only on these premises, we could reach objective history. We cannot have objective history if it is based on emotions without facts. I can say that I'm a Bosniak and I love 
my nation and I will now write against the other nations and for my own people without any facts. If I don't have documents for that or evidence, my writing is worthless. [...] Here we have one true historical tragedy when we talk about Bosniaks, objectively one true tragedy that was always created by groups that didn't have good intentions, not complete ethnic groups, but from those radical chauvinistic groups of the Serb and eventually the Croat nation. I will briefly go through the history [...].

In this excerpt, the lecturer reinforces his disapproval of nationally divided universities. He claims that even so-called national subjects do not have to be taught separately so long as they are based on objective science. In the case of history, the lecturer argues that objective history is possible only if one excludes (national) emotions. If history is based on facts and excludes emotions, it can be objective and therefore attractive to all students regardless of their nationality. However, when we examine the last paragraph of the interview cited above, it becomes evident that the decision of what is defined as an objective fact lies solely with the respective historian. It is the authority his words are granted that enables him to claim objective history for himself while denying it to a national counterpart.

As will be explored further in the remainder of the chapter, the victimisation of the Bosniak people is at the centre of the Bosniak local history representation. This is also the point from which the lecturer begins his narration, as indicated in his last paragraph cited above, in which he legitimises what happened to the Bosniaks as objective historical fact by using phrases such as 'historical tragedy', a 'true tragedy' and 'objectively one true tragedy' in the same sentence. As I will explore in the next section, the Bosniaks, unlike the Croats, do not draw the same conclusion about their perceived historical role as victims.

\section{National Aspirations and Connecting Different Historical Periods}

At the university lectures I followed, generally little attention was paid to the atrocities committed by one's own national group or to the atrocities experienced by others, while the victimisation of one's own group took centre stage. 'National historians have a propensity to characterize perpetrators 
from their national group as renegades committing isolated acts, while perpetrators from rival groups are portrayed as acting out the historical will of the offending nationality' (Donia 2000: 358). While the Bosniaks locate their victimhood first and foremost in the war of 1992-1995 and in the WWII period, the Croats locate it first and foremost in the time of Tito's Yugoslavia, the 1992-1995 war and the post-war (post-1995) period. Although I will focus on the accusations made by Bosniaks and Croats against each other, it is important to stress that Croats as well as Bosniaks make strong accusations against Serbs, too. The Serbs are presented as the initiators of the war by Croats and Bosniaks alike. However, since the present conflict lines in Mostar run between Bosniaks and Croats, little attention is paid to the third warring party, the Serbs. This is because the battle with the Serbs lies more in the past, while for people in Mostar the battle between Bosniaks and Croats is clearly situated in the present, refers to events in the past, and is all about the future.

In contrast to Sveućiliste where national liberation was proposed as the only path towards democracy, strong scepticism was expressed at Džemal Bijedic over the feasibility of constructing $\mathrm{BiH}$ as a nation-state. The claim that $\mathrm{BiH}$ has always been a multinational place and must remain one is central to the Bosniak-dominant public discourse. In the interview I conducted with the lecturer introduced above, this position becomes very clear:

Bosnia and Herzegovina cannot be constituted as a nation-state. Persistent attempts to create a nation-state here caused problems; today we have one monster of a state just because of this idea to create a nation-state. We cannot create a nation-state because history doesn't allow us to do that. We can create a civil state and that is the only way, there is no other!

In the Bosniak-dominant discourse, $\mathrm{BiH}$ is presented as a state that always has been and should therefore remain multinational. Faruk, another Bosniak historian, teaching history in one of Mostar's secondary schools, put it in these words in an interview I conducted with him:

In reality, Bosnia has always been a multilateral community. What the European Union is today, a mixture (mješavina) of different nations, a 
mixture, Bosnia has always been. Bosnia never has been unilateral. She has always been multilateral. [...] The recent war put Bosnia in great danger. Why? Because a great percentage of local Serbs_-Bosnian Serbs_-and a great percentage of Bosnian Croats during this war began to turn against, to destroy and to fire at their mother, their Bosnia, their mother, their land, with the goal of killing an entire people, the Bosniaks. And that is a historical fact.

In this narrative, the Croats as well as the Serbs are polemically represented as traitors who have no respect for the nature of $\mathrm{BiH}$, which is portrayed as multinational (see Alićehajić 2004). Croats and Serbs-or a great percentage of them, as Faruk put it-viewed the loss of the Bosniak people with complacency simply in order to achieve their goal of becoming a nation-state. Faruk backed up his last statement with the words 'and that is a historical fact'.

A multinational and centralised state, supported by the two historians discussed above, is a central claim in the Bosniak-dominant public discourse, which is supported by the Bosniak politicians in power. A multinational and centralised state would also ensure Bosniaks, who are in the numerical majority, a privileged status. In addition, the desire for more centralisation is in line with EU regulations that also demand a more centralised state. On the other hand, the notion of such a state is heavily contested by BiH's Croats as well as Serbs, who are afraid of losing power to the Bosniaks. While the Serbs insist on the continuation of the Serb Republic, key Croat political players demand more independence for the Croat population, sometimes expressed in the insistence on a Croat republic modelled after the already existing Serb Republic. The lecture series I attended at Sveuciliste communicated the opposite message from the one promoted by Bosniak historians: Croats have been suppressed throughout history and only national liberation ensures the freedom of the Croat nation. Thus local history was taught as a narrative of Croat suppression and their struggle to overcome it.

At Sveuciliste the period of Yugoslavia was central to the lecture series I attended; it was presented as a dark period that needed to be overcome in order to achieve national liberation. The lecturer who taught the lecture series was not cagey about his negative feelings towards Yugoslavia. 
He once told his students that one can only laugh at people who remember Yugoslavia nostalgically as he was sure they did so only because they were sentimental about the time they were young and healthy.

For the lecturer, the period of Yugoslavia was only about the suppression of the Croat nation. He holds Tito responsible for trying to eliminate national identity through attempts to create a meta-ethnic nationalism. 'Such a nationalism is a nice idea', the lecturer said somewhat sarcastically, 'but impossible to realise'. He told the students that at the beginning of the 1960s Tito gave in to political pressure and spoke publicly about nationalism for the first time although he was afraid that nationalism would lead to secession movements. Shortly afterwards, in 1967, Tito granted the Muslim population a national identity. ${ }^{14}$ For the lecturer, this move by Tito, together with Serb dominance, further strengthened the oppression of the Croat nation. Another example he provided to underline the institutionalised disempowering of the Croat people was Tito's apparent gerrymandering of municipality borders in order to prevent Croats from gaining a majority. The lecturer presented Tito to his students as a statesman who sought to erase national feelings; yet, so the lecturer argued, nationalism (national liberation) is crucial for achieving democracy.

In both the Bosniak- and Croat-dominant public discourses, the past is presented in such a way that it serves to legitimise the respective national aspirations. Therefore, as argued earlier in this book, representations of the past are likely to tell us more about the present state and about aspirations for the future than they actually tell us about the past itself. This is true in both Bosniak- and Croat-dominant discourses, where not only is the past represented in often diametrical ways, but so are the future aspirations of the respective nation. In order to validate the suffering of their own nation, different historical periods are strung into one coherent narrative, a narrative of victimisation and suppression. It is indeed a central discursive strategy in the Croat- as well as the Bosniak-dominant public discourse, and is also a tool heavily drawn upon in school history textbooks in $\mathrm{BiH}$ :

\footnotetext{
${ }^{14}$ From then on people could choose the category Muslim (national) in the census while before they could only choose between Muslim (religious), undeclared or Yugoslav. Tito's motivation for granting Muslims a national status was to counter-balance the nationalism of the two big nations (Serb and Croat) (Isakovic 2000: 80-81).
} 
Generally entire chapters [...] could have been analysed from the point of view of how they serve to make the present more understandable by equalising the past and the present. Numerous direct and indirect references across time construct the idea of historical continuity and reoccurrence when the construction of representations of nation, war and peace in the history textbooks is in question. This is true among all three communities. (Torsti 2003: 253)

Among local historians, a central discursive strategy was the linking of the recent with the more distant past, even if the latter was not officially the object of study. Numerous connections to the distant past were made in order to reinforce the ancient history of the Croat nation and to point out the animosities that Croats have faced throughout time. At the end of one lecture in which the national movement was discussed, the lecturer suggested a topic for the students' final paper: the oppression of the Croat people, from the Ottoman Empire through to Tito's Yugoslavia.

The lecturer painted a picture of the Croats as 'a nation in captivity' during the socialist era. The Croats are presented as a suppressed and discriminated nation that was also economically exploited. This discourse is also dominant in Croat history textbooks (Dimou 2007: 131). Moreover, Croats are presented as truly liberal:

Croatian political identity is portrayed as primordially liberal and conversely, liberalism is identified as the essential political orientation of the Croatian nation. As a narrative strategy it is inserted with the intention to individualize Croatian history and remove any common frame of reference to the second Yugoslavia. (Dimou 2007: 140)

This strategy pointed out by Dimou implies that the Croats did not participate in Tito's socialist project whatsoever. In this national master narrative, Croat liberation was realised with the Homeland War 1991-1995 (domovinski rat) that led to Croatia's independence (although independence was only fully realised for the Croats in Croatia and not for the Croats in $\mathrm{BiH}$ ). As evident later in this chapter and in some of my interlocutors' narratives in Chaps. 4-6, the fear is that owing to the numerical minority of Croats in $\mathrm{BiH}$, Croats will not be able to maintain their independence as a nation and, in the worst-case scenario, will disappear 
altogether (through emigration and assimilation). This fear is taken as justification by Croats for claiming further national independence. From the time the Bosnian Croats gave up their hopes of joining Croatia, claims have been made for a separate Croat republic.

In the Bosniak-dominant public discourse, the linking of different historical periods is enacted in order to prove the continuous victimisation of the Bosniak people since the decline of the Ottoman Empire, with a short interruption during Tito's Yugoslavia. Bosniaks are ascribed a victim status, while Croats and Serbs are presented as perpetrators who disregarded the Bosniaks as a distinct people and aimed to conquer them. In order to validate past Bosniak victimisation, the historians linked different historical periods. Sometimes the links are explicit, while at other times the leaping between different historical periods implies that there should be a correlation between them. The war in the 1990s thereby is presented as if it were only the latest historical example of Bosniak suffering and victimhood. In this narrative, the Croats and Serbs are perceived as threats to the Bosniak nation because of their denial of the latter's independent existence. In contrast, Bosniaks present themselves as a nation that respects the other nations. Particularly prominent is the linking of WWII with the recent war. I will use one specific narrative conveyed to me by the history teacher Faruk to demonstrate this linking strategy.

When narrating the local history of the 20th century, two concepts were predominant for Faruk: fascism and genocide. He made an explicit connection between WWII and the recent war, which for him were both initiated by Croat and Serb fascists who committed genocide but were finally defeated. Faruk told me that his elaborations on WWII were necessary in order for me to understand the recent war in $\mathrm{BiH}$. At one point during his narration he stated:

Serb nationalists, a horde of Chetnics, a fascist unit started a massive slaughter (klanje) against the Muslim residents. That was indeed awful; unfortunately it repeated itself 50 years later [...].

Faruk cemented this link between the two wars because of the recurring importance of a specific date, which he took as proof that the recent 
war was a repetition of WWII. He underpins the connection between the aggression against $\mathrm{BiH}$ /against the Bosniak nation (he uses the two interchangeably) by fascists during WWII and the war of 1992-1995, by calling attention to the date of 9 November:

Mostar first went through destruction performed by the Serb fascists, and then it went through destruction, an urbicide committed by HVO. And in this phase of aggression it came to the final destruction of the Old Bridge, I told you already a few days ago, 09 November 1993. This date is deliberately chosen. On the same day 60 [55!] years earlier, on 09 November 1938, the Kristallnacht (Night of Broken Glass) had taken place in Hitler's Nazi Germany, which marked the beginning of the Holocaust against the Jews and everything that took place thereafter in occupied Europe. And on that date [09 November 1993] the Old Bridge in Mostar was destroyed! [...] The destruction of the Old Bridge indeed was a sign for the Croat fascists that the Holocaust of the Bosniaks had begun like the Kristallnacht in Nazi Germany signalled the beginning of the Holocaust of the Jews. The destruction of the Old Bridge for them meant the elimination, the extermination of Bosniaks at the riverbank. But that is monstrous, because the Old Bridge is a symbol of Bosniaks, but also of Serbs and Croats and Jews and of the entire world!

The close connection Faruk draws between WWII and the recent war, and the way he presents Bosniaks as the victims (like the Jews during WWII), while presenting the Croats and Serbs as fascist aggressors (like the Nazis), is characteristic of the dominant Bosniak public discourse. ${ }^{15}$ In this discourse, the term 'genocide' is used freely for different kinds of atrocities committed against the Bosniak population. This is also common practice in Bosniak history textbooks (see Karge 2008: 15; see also Torsti 2003). The term genocide in textbooks is used not only for the killing of Bosniaks during 1992-1995, but also for the Ustaša policy that aimed to assimilate Bosniaks. Even the early years of the interwar kingdom (1921-1929) are described as 'political genocide of the Muslims' (Ramet 2007). It is a common discursive strategy in Bosniak as well as in Croat and Serb textbooks to describe local history by using the same

\footnotetext{
${ }^{15}$ The close link drawn between the recent war and WWII also becomes visible in the commemorations held on 9 May in East Mostar, at the so-called Victory Day over Fascism (Dan pobjede nad faśizmom).
} 
terms for different historical periods. In the case of the Bosniaks, textbook authors suggest that the recent war can be explained (and perhaps could even have been foreseen) by events in the past, by the decade-long (or even century-long) hostility of Croats and Serbs against Bosniaks (see Torsti 2003: 255). ${ }^{16}$

\section{Towards Multi-Perspectivity}

As has been shown, while Bosniak and Croat historiographies could hardly be more antithetical, the central discursive strategies employed by the historians are similar in many ways. This is particularly true for the discursive strategy of linking different historical periods in order to achieve a coherent national narrative that serves present political purposes. This linking is used to incorporate the war of 1992-1995 into the meta-narrative, even if it is not an explicit subject of discussion, as well as to justify aspirations for the nations' respective futures. In this sense, the way that history is narrated by the historians presented in this chapter is strongly goal-oriented. Michael Bakhtin's notion of chronotope (Bakhtin 1981) is illuminating since it pays attention to specific configurations of the time/space relationship in discourse and ' $(. .$.$) the artful interwining of chronotopes can$ create discursive connections among moments presumed to be differently located in time and space' (French 2012: 346). As Bauman reminds us: 'Connecting events that are separated in time and often space involves an active social process of extracting discourse from one setting and inserting it into a new setting' (Bauman 1986: 22).

Besides linking different chronotopes, discursive strategies of claiming authority and objectivity over history were enacted at both the Bosniak- and the Croat-dominated universities. Rather than providing sources on which a specific interpretation is based, the lecturers made claims that were based on their own authoritative position as historians. The lecturers largely gave direct instructions to the students on how local history should be understood. Rather than being based on a critical

\footnotetext{
${ }^{16}$ Such strategies are also prominent in textbooks of other similarly divided societies. In Greek and Turkish Cypriot textbooks, for example, national narratives present the future as historically determined (Papadakis 2008).
} 
reading of texts, the lecturers gave the students 'historical facts'. This is the way that history is taught to younger pupils as well, as I learned during a workshop on multi-perspective textbook writing organised by the OSCE together with the Georg Eckert Institute for International Textbook Research. History textbooks used in $\mathrm{BiH}$ are often written in an encyclopaedic style (listing historical 'facts') and do not encourage pupils and teachers to engage with different perspectives of historical events. There is little room for either interpretation or discussion, and the history of everyday life (e.g., from the period of Tito's Yugoslavia) is entirely excluded from most textbooks.

This workshop had invited potential history textbook authors who were interested to rethink traditional textbook writing and to investigate new ways of teaching history (see Stradling 2001, 2005). Its main aim was to discuss multi-perspectivity in textbooks, the goal of which was to create room for discussion in the classroom and enable students to judge where to locate historical truth themselves. ${ }^{17}$ Although university students are sometimes invited to participate in such discussions in their classrooms, they are quickly reprimanded if their representations of history do not correspond with the one authorised by the lecturer. Notwithstanding this bias, or perhaps precisely because of it, the objectivity of historiography is constantly emphasised by Bosniak and Croat historians. Nationalising the past goes hand in hand with a coherent authoritarian narration, which does not allow any room for multi-perspectivity.

Even if in this chapter the Bosniak and Croat public dominant discourses were discussed separately from the narratives of the three generations, I am by no means suggesting that we can clearly delineate between the two types of narration. The differentiation I make is an analytical rather than a real one, as it were. As pointed out in the Introduction, the differentiation between discursive strategies (identified in the dominant public discourses) and discursive tactics (identified in the narratives

\footnotetext{
${ }^{17}$ One project aiming for multi-perspectivity was initiated in 2003 by a group of historians from Bosnia and Herzegovina, Croatia and Serbia under the umbrella of EUROCLIO (the European Association of History Educators) and resulted in a joint textbook Obični ljudi u neobičnoj zemlji, svakodnevni život u Bosni i Hercegovini, Hrvatskoj i Srbiji 1945-1990. Jugoslavija izmedu Istoka i Zapada (Ordinary People in an Extraordinary Country-Every Day Life in Bosnia and Herzegovina, Croatia and Serbia 1945-1990. Yugoslavia between East and West). In a conversation with one of the authors, I was told that until today only a small number of copies have found their way into the classroom.
} 
of the three generations) makes clear that individuals who are not professionally involved in (re-)writing the past locate their narratives and interpretations of the past in a field predefined by the dominant public discourse, but at the same time they are not fully determined by it. There is no direct transmission between teachers/professors and pupils/students nor is there a direct transmission of 'collective memories' from generation to generation. As will be shown in the following chapters, individuals make use of the dominant public discourses in different ways and their narratives are never independent from them (even if they position themselves strongly against them). The process of making meaning of past events and periods is socio-culturally situated and is always coconstructed and dialogical (Bakhtin 1981). Personal narratives are informed (but not determined) by current dominant public discourses as well as by past dominant public discourses that individuals of different generations have been exposed to (particularly during formative and educative years).

Even if this means that personal narratives cannot be neatly separated from the dominant public discourses promoted by professionals involved in the 'national project', an analytical differentiation helps to carve out the particular ways by which individuals of different generational positioning reposition themselves vis-à-vis the past after great political changes have occurred. Moreover, it allows us to take into consideration the impact on and responses to dominant public discourses by individuals, who draw on a specific range of personal experiences and share a certain stage of life, a certain life situation.

\section{Bibliography}

Alićehajić, Kemal. 2004. Horde zla u Mostaru. Tešanj: Bibloteka Logos.

Ashton, Carolyne. 2007. Evaluation Report on Progress Made through the OSCE's

Efforts to Unify the Gymnasium Mostar: Summer 2003 to Fall 2006. Sarajevo:

OSCE.

Bakhtin, Michael. 1981. The Dialogic Imagination: Four Essays. Austin: University of Texas Press.

Bauman, Richard. 1986. Story, Performance, and Event: Contextual Studies of Oral Narrative. Cambridge: Cambridge University Press. 
Borneman, John. 1992. Belonging in the Two Berlins: Kin, State, Nation, Cambridge Studies in Social and Cultural Anthropology. Cambridge: Cambridge University Press.

Bourdieu, Pierre. 1992. Language and Symbolic Power. Cambridge: Polity Press. Original edition, 1991.

Campbell, David. 1998. National Deconstruction: Violence, Identity, and Justice in Bosnia. Minneapolis, MN: University of Minneapolis Press.

Dimou, Augusta. 2007. Present's Past: The National History of Socialism or the Socialist Period of the Nation? Representations of Communist Yugoslavia in the Textbooks of the Successor States. In Zwischen Amnesie und Nostalgie: Die Erinnerung an den Kommunismus in Südosteuropa, eds. U. Brunnbauer and S. Troebst, 131-151. Cologne: Böhlau.

Donia, Robert J. 2000. Review Article the New Bosniak History. Nationalities Papers 28(2): 351-358.

. 2010. The New Masters of Memory. Libraries, Archives, and Museums in Postcommunist Bosnia-Herzegovina. In Archives, Documentation, and Institutions of Social Memory, eds. F.X. Blouin Jr. and W.G. Rosenberg, 393401. Ann Arbor, MI: University of Michigan Press.

Fairclough, Norman. 1992. Discourse and Social Change. Cambridge: Polity.

French, Brigittine. 2012. The Semiotics of Collective Memories. Annual Review of Anthropology 41: 337-353. Annual Reviews.

Hewstone, Miles et al. 2005. Intergroup Contact in a Divided Society: Challenging Segregation in Northern Ireland. In Social Psychology of Inclusion and Exclusion, edited by D. Abrams, M. A. Hogg and J. M. Marques. New York: Psychology Press, 245-264

Hill, Kelly. 2011. Possibilities for Social Cohesion in Education: BosniaHerzegovina. Peabody Journal of Education 86(2): 155-170.

Höpken, Wolfgang. 2002. History - Textbooks and Reconciliation - Preconditions and Experiences in a Comparative Perspective. World-Bank meeting. Washington, DC, 11 November 2002. http://siteresources.worldbank.org/ INTCEERD/Resources/EDUCwolfganghopken.pdf [20.07.2010].

Hromadžić, Azra. 2008. Discourses of Integration and Practices of Reunification at the Mostar Gymnasium, Bosnia and Herzegovina. Comparative Education Review 52(4): 541-563.

- 2015. Citizens of an Empty Nation: Youth and State-Making in Postwar Bosnia-Herzegovina. Philadelphia: University of Pennsylvania Press.

Isakovic, Zlatko. 2000. Identity and Security in Former Yugoslavia. Aldershot: Ashgate. 
Karge, Heike. 2008. 20th Century History in the Textbooks of Bosnia and Herzegovina: An Analysis of Books Used for the Final Grades of Primary School. Sarajevo: OSCE.

Kolstø, Pål. 2005. Myths and Boundaries in South-Eastern Europe. London: Hurst \& Co.

Lederach, John P. 1997. Building Peace: Sustainable Reconciliation in Divided Societies. Washington: United States Institute of Peace Press.

Melčić, Dunja. 2007. Der Diskurs über die Vergangenheit in Kroatien. In Schnittstellen: Gesellschaft, Nation, Konflikt und Erinnerung in Südosteuropa, eds. E. Hösch and K. Clewing, 547-560. Munich: R. Oldenbourg Verlag. Mills, Richard. 2010. Velež Mostar Football Club and the Demise of 'Brotherhood and Unity' in Yugoslavia, 1922-2009. Europe-Asia Studies 62(7): 1107-1133.

OSCE. 2007a. Tailoring Catchment Areas. School Catchment Areas in Bosnia and Herzegovina. Sarajevo: OSCE.

- 2007b. Slipping through the Cracks: School Enrolment and Completion in Bosnia and Herzegovina. Sarajevo: OSCE.

. 2007c. Education Inspectors: A Neglected Resource. Overview of Status and Activities of Education Inspectors in Bosnia and Herzegovina. Sarajevo: OSCE.

. 2007d. Lessons from Education Reform in Brčko. Sarajevo: OSCE.

- 2007e. Towards Inter-Religious Understanding in Bosnia and Herzegovina: A Status Report on the Pilot Course Culture of Religions. Sarajevo: OSCE.

OSCE. n.d. Compendium of Selected Reports on Education in Bosnia-Herzegovina 2004-2005. Sarajevo: OSCE.

Palmberger, Monika. 2013. Acts of Border Crossing in Post-War Bosnia and Herzegovina: The Case of Mostar. Identities: Global Studies in Culture and Power 20(5): 544-560.

Papadakis, Yiannis. 2008. Narrative, Memory and History Education in Divided Cyprus. A Comparison of Schoolbooks on the "History of Cyprus". History \& Memory 20(2): 128-148.

Purdeková, Andrea. 2008. Building a Nation in Rwanda? De-Ethnicisation and Its Discontents. Studies in Ethnicity and Nationalism 8(3): 502-523.

Ramet, Sabrina P. 2007. The Dissolution of Yugoslavia: Competing Narratives of Resentment and Blame. Südosteuropa 55(1): 26-69.

Sekulić, Gajo. 1999. Fünf Paradoxa der Menschenrechtsfragen vom Standpunkt der ethischen Rekonstruktion der Geistes- und Sozialwissenschaften in Bosnien-Herzegowina - Thesen. In Menschenrechte in Bosnien und Herzegowina: Wissenschaft und Praxis, ed. W. Benedek, 273-283. Vienna: Böhlau. 
Stradling, Robert. 2001. Како предавати историју Eвропе 20. вијека [Teaching 20th-Century European History]. Strasbourg: Council of Europe Publishing.

. 2005. Multiperspektivnost u nastavi iz historije: Upustvo za nasavnike. http://www.coe.int/t/dg4/education/historyteaching/Source/Notions/ Multiperspectivity/MultiperspectivityBosnian.pdf [20.04.2010].

Swimelar, Safia. 2013. Education in Post-War Bosnia: The Nexus of Societal Security, Identity and Nationalism. Ethnopolitics 12(2): 161-182.

Torsti, Pilvi. 2003. Divergent Stories, Convertent Attitudes: Study on the Presence of History, History Textbooks, and the Thinking of Youth in Post-War Bosnia and Herzegovina. Dissertation, Faculty of Social Sciences, University of Helsinki. Ugrešić, Dubravka. 1998. The Culture of Lies: Antipolitical Essays. University Park, PA: Penn State University Press.

Univerzitet Mostar. 2002. 1977-2002. 25 Godina Univerziteta "Dzemal Bijedic" u Mostaru. Mostar: CIP.

Van der Veer, Peter. 2002. The Victim's Tale: Memory and Forgetting in the Story of Violence. In Religion between Violence and Reconciliation, ed. T. Scheffler, 229-242. Beirut: Ergon Verlag.

Vuckovic Juros, Tanja. 2012. Social Changes and the Generational Differences in the Formation of Collective Memories. Dissertation at Indiana University. ProQuest dissertations and theses. http://gateway.proquest.com/openurl?url_ver=Z39.882004\&res_dat=xri:pqdiss\&rft_val_fmt=info:ofi/fmt:kev:mtx:dissertation\&rft_ dat=xri:pqdiss:3552643 [17.07.2015].

Weber, Bodo. 2007. Kriza univerziteta i perspektive mladih naučnika u Bosni i Hercegovini [The Crisis of the Universities in Bosnia and Herzegovina and the Prospects of Junior Scholars]. Sarajevo: Friedrich Ebert Stiftung.

Wertsch, James. 2002. Voices of Collective Remembering. Cambridge: Cambridge University Press.

Open Access This chapter is distributed under the terms of the Creative Commons Attribution 4.0 International License (http://creativecommons.org/licenses/by/4.0/), which permits use, duplication, adaptation, distribution, and reproduction in any medium or format, as long as you give appropriate credit to the original author(s) and the source, a link is provided to the Creative Commons license, and any changes made are indicated.

The images or other third party material in this chapter are included in the work's Creative Commons license, unless indicated otherwise in the credit line; if such material is not included in the work's Creative Commons license and the respective action is not permitted by statutory regulation, users will need to obtain permission from the license holder to duplicate, adapt or reproduce the material.

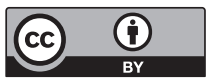

